\title{
Energy balance of biogas production from microalgae: Development of an energy and mass balance model
}

\author{
John J Milledge ${ }^{1 *}$ and Sonia Heaven ${ }^{1}$ \\ ${ }^{1}$ Engineering and the Environment, University of Southampton \\ ${ }^{* 2}$ Current Address for Corresponding Author; Engineering and Science, University of \\ Greenwich, *email j.jmilledge@gre.ac.uk
}

\begin{abstract}
The paper describes the construction of a mechanistic energy balance model for the production of biogas from anaerobic digestion of microalgal biomass grown in raceways, based on simple principles and taking into account growth, harvesting and energy extraction. The model compares operational energy inputs with the calorific value of the output biomass in terms of the energy return on operational energy invested (EROOI). Initial results indicate that production of microalgal biogas will require:

a) Favourable climatic conditions. The production of microalgal biofuel in the UK would be energetically challenging at best.

b) Achievement of 'reasonable yields' equivalent to $\sim 3 \%$ photosynthetic efficiency $\left(25 \mathrm{~g} \mathrm{~m}^{-2}\right.$ day $\left.^{-1}\right)$.

c) Low or no cost and embodied energy sources of $\mathrm{CO}_{2}$ and nutrients from flue gas and wastewater.

d) Mesophilic rather than thermophilic digestion.

e) Adequate conversion of the organic carbon to biogas $(\geq 60 \%)$.
\end{abstract}

The model itself provides a powerful assessment tool both for comparison of alternative options and potentially for benchmarking real schemes.

Keywords: Microalgae; algae; Bioenergy; Biogas; Anaerobic digestion; Energy balance 


\section{Introduction}

The potential of microalgal biomass as a source of liquid and gaseous biofuels has been a highly topical issue in the past few years (1). In theory a wide range of unit operations can be combined to form microalgal biofuel production systems; as yet, however, there is no successful commercial system producing such biofuel (2-4). This suggests that there are major technical and engineering difficulties to be resolved before economically viable microalgal biofuel production can be achieved.

One measure of the real or potential performance of a biofuel production system is the energy return on energy investment (EROEI or EROI), which is the ratio of the energy produced compared to the amount of energy invested in its production. This 'simple' ratio can be useful in assessing the viability of fuels: a ratio of less than one indicates that more energy is used than is produced, and an EROI of 3 has been suggested as the minimum that is viable (5). A recent extensive review and life cycle assessment (LCA) using a Monte Carlo approach found that nearly half of all LCA results had an EROI of less than one (6).The Sills (2012) study showed, however, that methane from anaerobic digestion of lipid-extracted algae is required for net gains in energy, and must be an integral part of algal biodiesel production to yield EROI values that are greater than one. A study by Wiley et al (7) concluded that anaerobic digestion is the most appropriate pathway for the exploitation of algae for energy. The current work therefore focused on development of a methodology for assessment of the energy balance for production of biogas from algal biomass.

Although LCAs are an accepted methodology for assessing the potential of algal energy production systems (8), Pfromm et al (9) have suggested that algal biofuel LCAs tend to focus on materials rather than processes. They are essentially an inventory that may lack the rigorous checks on data consistency offered by an engineering mass and energy balance; and the expansion of LCAs to provide energy balances is thus not an optimal approach (9). This paper describes the development of a mechanistic energy balance model for microalgal biofuel production from open raceway systems which is capable of determining the energetic viability of the process under different scenarios and harvesting methods.

In the calculation of an EROI the definition of a consistent set of system boundaries for energy inputs and outputs can be very challenging; and while incorporating energy values for all of the 
non-energy inputs and co-products may appear to give the most comprehensive measure of performance, it may also be the least precise (10). Even peer-reviewed and published studies are sometimes unclear concerning what is included within a particular calculation (11). EROIs often exclude the embodied energy of process equipment, and reports indicate this is not a major factor in the production of microalgal biofuels $(6,12,13)$. The main energy inputs in microalgal biofuel production are operational energy and the embodied energy of nutrients (12).

In the current work, the embodied energy within process equipment was not included within the energy balance. The embodied energy of materials has also been excluded, apart from where referenced in the discussion, and the use of sources of water, nutrients and $\mathrm{CO}_{2}$ with 'low' embedded energy, such as wastewater and flue gas has been assumed throughout. The inputs are thus the operational energy requirements, in terms of heat and electricity, of the process equipment. The output was the higher heating value (HHV) of the biomass or, where biogas was the end product, of the methane in the predicted biogas production. The term energy return on operational energy invested (EROOI), i.e. the ratio of the energy output to the operational energy input, has been used in this work.

\section{Model construction}

\subsection{Model structure and assumptions}

The energy and mass balance model for microalgal biogas production was developed and implemented in a Microsoft Excel spreadsheet. The model was divided into three main operational areas: growth, harvesting and energy extraction (Figure 1). The areas are linked by a requirement for pumping power, which has not been fully accounted for in many studies (14). The model comprises nine worksheets, and was built up from fundamental equations such as those for fluid flow in pipes (15); and from literature values for physical constants. 


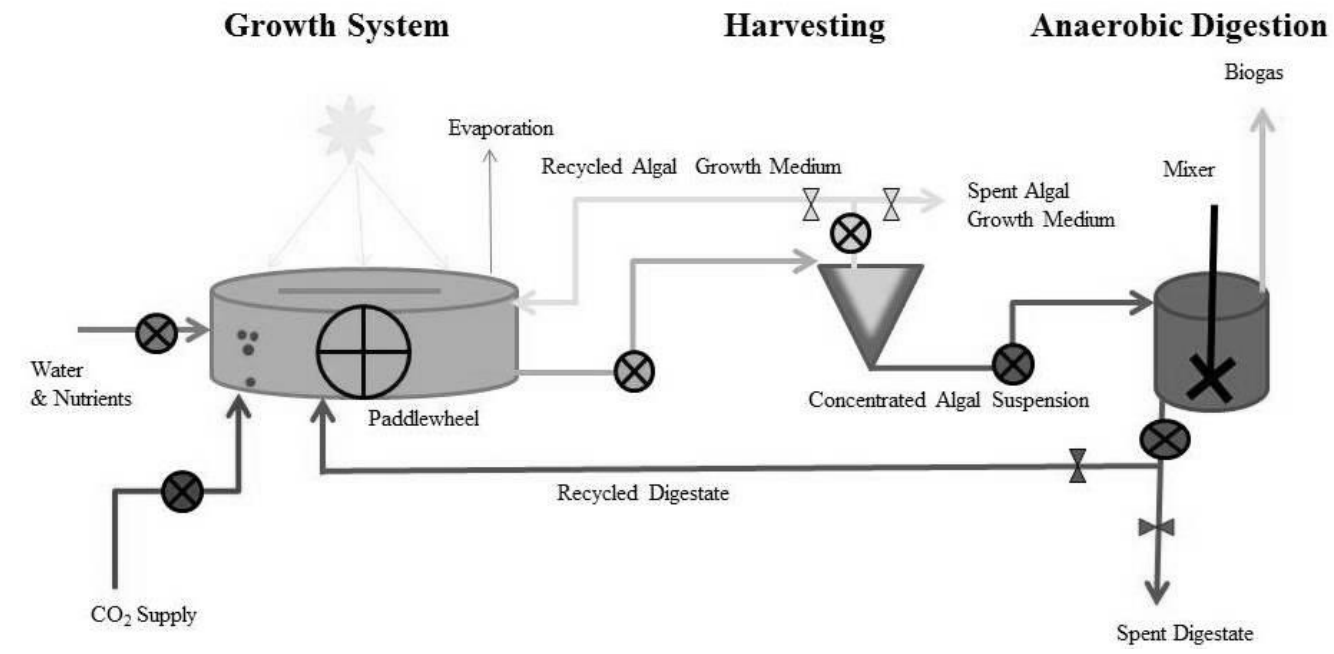

Figure 1 Excel model simplified process flow diagram

The model construction is described below, with additional details and specific assumptions discussed in the appropriate results and discussion sections.

\subsubsection{Microalgal biomass and biogas yields}

The calorific value of algal biomass was calculated using the annualised solar insolation and overall photosynthetic efficiency (16-18). Algal biomass was assumed to consist of lipids, carbohydrates, proteins and inorganic material. The proportion of each component can be set from $0-100 \%$ with the total always being $100 \%$. Default values were assumed of $20 \%$ lipids, $30 \%$ carbohydrates, $50 \%$ proteins and $0 \%$ inorganic material, equivalent to a typical empirical formula of $\mathrm{C}_{1} \mathrm{H}_{1.8} \mathrm{O}_{0.5} \mathrm{~N}_{0.1}(19,20)$.

The HHV of the algal biomass was calculated using a version of the Dulong equation (21)

Equation 1

$$
\mathrm{HHV}\left(\mathrm{MJ} \mathrm{kg}^{-1} \text { dry fuel }\right)=\frac{34.1 \mathrm{C}+102 \mathrm{H}+6.3 \mathrm{~N}+19.1 \mathrm{~S}-9.850}{100}
$$

where $\mathrm{C}, \mathrm{H}, \mathrm{N}, \mathrm{S}$ and $\mathrm{O}$ are the carbon, hydrogen, nitrogen, sulphur and oxygen in the biomass expressed as \% VS; in the absence of values for sulphur this component is taken as zero.

Biomass yield was calculated from the calorific yield and the estimated HHV of the microalgae (16). 
Potential methane and biogas yields were estimated from the empirical chemical formulae using the Buswell equation $(22,23)$. The $\mathrm{HHV}$ of methane was taken as $55.662 \mathrm{KJ} \mathrm{g}^{-1}$ at $0^{\circ} \mathrm{C}$ and $101.325 \mathrm{kPa}(24)$.

\subsubsection{Growth system}

Open raceways were selected as the growth system because the overwhelming balance of published information indicates that the energy inputs and costs of producing microalgal biomass in open systems are significantly lower than in closed photobioreactors (PBRs) $(7,13$, 25-27). The main energy inputs in raceways are for 'mixing' and gas transfer.

\subsubsection{Paddlewheel 'mixing' energy}

Mixing in the raceway was assumed to be by a paddlewheel, and the power and energy requirements were calculated using equations for open channel flow in raceways (28-30).

\subsubsection{Gaseous transfer energy}

The carbon source for microalgal growth was assumed to be gaseous $\mathrm{CO}_{2}$ supplied from a waste source, such as flue gas or biogas upgrading, and the $\mathrm{CO}_{2}$ concentration of the gas stream could be varied between $0-100 \%$. Gas was assumed to be bubbled into the cultivation medium via a sparger in a sump, with the total pressure drop being the sum of the hydrostatic head above the sparger, and the pressure drop across the sparger from friction losses in the supply pipework. It was assumed that $\mathrm{CO}_{2}$ was supplied during daylight hours, for an average of 12 hours per day.

The model allows both the sump depth and the sparger pressure drop to be set to any value. A typical pressure drop across a sparger of $6.89 \mathrm{kPa}$ was assumed (31). A sump depth of $2 \mathrm{~m}$ was selected, as recent work has shown that a simple $1.8 \mathrm{~m}$ deep sump can transfer $90 \%$ of the $\mathrm{CO}_{2}$ from flue gas (32).

The model assumes adiabatic compression to calculate the energy required for gaseous exchange in the raceway, based on equations 2 and 3 :

Equation 2

$$
\mathrm{T}_{\text {out }}=\mathrm{T}_{\text {in }}\left(\frac{\mathrm{p}_{\text {out }}}{\mathrm{p}_{\text {in }}}\right)^{((\mathrm{z}-1) / \mathrm{z})}
$$


Where $\mathrm{z}$ is the ratio of specific heat at constant pressure to specific heat at constant volume, and was taken as 1.4 as for air (33). $\mathrm{T}_{\text {in }}$ and $\mathrm{T}_{\text {out }}$ are temperatures (degree $\mathrm{K}$ ) in and out of the compressor and $\mathrm{p}_{\text {in }}$ and $\mathrm{p}_{\text {out }}$ are pressures $(\mathrm{Pa})$ in and out of the compressor.

Equation 3

$$
\text { Adiabatic Power (ideal gas) }=\mathrm{M}^{*} \mathrm{C}_{\mathrm{p}} *\left[\mathrm{~T}_{\text {out }}-\mathrm{T}_{\text {in }}\right]
$$

Where $\mathrm{M}\left(\mathrm{kg} \mathrm{s}^{-1}\right)$ is mass flow and $\mathrm{C}_{\mathrm{p}}$ is specific heat capacity at constant pressure, taken as $1.005 \mathrm{~kJ} \mathrm{~kg}^{-1} \mathrm{~K}^{-1}$ for air (33).

The mass flow requirement was determined based on the $\mathrm{CO}_{2}$ requirement for algal growth, calculated from the percentage of carbon in the microalgal biomass. An 80\% transfer of carbon dioxide in the bubble to the growth media was assumed. Weissman, Tillett (34) found 78-90\% of $\mathrm{CO}_{2}$ in gas bubbles was transferred in large-scale open raceway sumps. Transfer declines exponentially with declining $\mathrm{CO}_{2}$ concentration in the gas, and higher transfer rates may not be economically attractive (25).

\subsubsection{Outgassing of $\mathrm{CO}_{2}$}

In addition to that used for growth, $\mathrm{CO}_{2}$ will be 'lost' to the atmosphere as the growth medium is circulated around the raceway.

In raceways, gaseous exchange will not only take place at the site of the addition of $\mathrm{CO}_{2}$ or flue gas (the sump), but also at the paddlewheel and around the entire raceway. Although high gas transfer coefficients occur at the paddlewheel, the low volume and the short residence time in the paddlewheel section result in lower gas transfer than the raceway and the sump (35). Gas transfer at the paddlewheel was therefore excluded in order to simplify the model. The rate of gas transfer can be expressed as:

Equation 4

$$
\frac{\mathrm{dC}}{\mathrm{dt}}=\mathrm{k}_{\mathrm{gt}}\left(\mathrm{C}_{\mathrm{s}}-\mathrm{C}_{\mathrm{o}}\right)
$$

where $\frac{\mathrm{dC}}{\mathrm{dt}}$ is the rate of gas transfer $\left(\mathrm{kg} \mathrm{m}^{-3} \mathrm{~s}^{-1}\right), \mathrm{k}_{\mathrm{gt}}$ is the gas transfer constant $\left(\mathrm{s}^{-1}\right), \mathrm{C}_{\mathrm{s}}$ is the saturation concentration of the gas and $\mathrm{C}_{0}$ the concentration of the gas in the fluid $\left(\mathrm{kg} \mathrm{m}^{-3}\right)$. 
The equation originally developed by Owens $(36,37)$ for depths of $0.1-3.0 \mathrm{~m}$ and fluid velocities of 0.03-1.5 $\mathrm{m} \mathrm{s}^{-1}$ was applied for calculation of gas transfer coefficients.

Equation 5

$$
\mathrm{k}_{\mathrm{gt}}=5.32 \frac{\mathrm{v}^{0.67}}{\mathrm{~d}^{1.85}}
$$

Where $\mathrm{d}$ is depth of the stream $(\mathrm{m})$ and $\mathrm{v}$ is the fluid velocity $\left(\mathrm{m} \mathrm{s}^{-1}\right)$.

The re-aeration coefficient for a $0.3 \mathrm{~m}$ deep raceway flowing at $0.3 \mathrm{~m} \mathrm{~s}^{-1}$ was calculated as 22 day $^{-1}\left(2.5 \times 10^{-4} \mathrm{~s}^{-1}\right)$ which was in the range of values from $1-4 \times 10^{-4} \mathrm{~s}^{-1}$ found for large and small experimental raceways (32).

The gas transfer coefficient used for $\mathrm{CO}_{2}$ was 0.923 times that for $\mathrm{O}_{2}(36)$, and mass transfer for outgassing $\mathrm{CO}_{2}$ can therefore be expressed as:

Equation 6

$$
\mathrm{k}_{\mathrm{gt} \mathrm{CO} 2}=0.923 * 5.32 \frac{\mathrm{v}^{0.67}}{\mathrm{~d}^{1.85}}
$$

Raceways typically exhibit plug flow behaviour, with little or no longitudinal mixing (38-41). The Streeter Phelps equation is normally used to model changes in dissolved oxygen (DO) with distance in rivers or streams behaving as plug flow reactors (37). A modified Streeter Phelps equation was applied to estimate $\mathrm{CO}_{2}$ outgassing, using the mass transfer coefficient calculated from Equation 6 to replace the $\mathrm{O}_{2}$ mass transfer coefficient.

\subsubsection{Accumulation of $\mathbf{O}_{2}$}

$\mathrm{O}_{2}$ produced during photosynthesis will accumulate in the fluid in the raceway until the concentration is such that the rate of outgassing is equal to that of net rate of production. The equilibrium concentration can then be determined using equation 7 .

Equation 7

$$
\mathrm{q}_{\mathrm{O} 2}=\mathrm{k}_{\mathrm{gt} 02}\left(\mathrm{C}_{\mathrm{o}}-\mathrm{C}_{\mathrm{s}}\right)
$$

where $\mathrm{q}_{\mathrm{O} 2}$ is the net rate of oxygen production from algal growth in the raceway $\left(\mathrm{kg} \mathrm{m}^{-3} \mathrm{~s}^{-1}\right)$. 


\subsubsection{Pumping}

The Darcy-Weisbach equation was used to calculate frictional head loss, $\mathrm{h}_{\mathrm{p}}(\mathrm{m})$ :

Equation 8

$$
h_{p}=f_{D} \frac{L}{D} \frac{v^{2}}{2 g}
$$

Where $D$ is the pipe diameter $(m)$ and head loss is a function of the friction factor $f_{D}$ which depends on the parameters of the pipe and the velocity of the fluid flow. For the laminar flow regime $(\operatorname{Re}<2000)$ roughness has no discernible effect and the friction factor was calculated from

Equation 9

$$
f_{D}=\frac{64}{R_{e}}
$$

For turbulent flow the friction factor was calculated from the simplified equation developed by (15) based on the Colebrook-White equation:

Equation 10

$$
f_{D}=1.14+2 \log _{10}\left(\frac{D}{e}\right)^{-2}
$$

Where $\mathrm{D}$ is pipe diameter (m) and e is average roughness (m). Both factors can be set to any value in the model. A default value of $0.046 \mathrm{~mm}$ was assumed for average roughness (e) (42). Typical commercial pipe diameters of $100 \mathrm{~mm}$ and $50 \mathrm{~mm}$ were also assumed. The diameter for the outflow pipe (50 or $100 \mathrm{~mm}$ ) for each pump was selected to give a flow velocity nearest to the suggested optimum of $3.0 \mathrm{~m} \mathrm{~s}^{-1}$ (42). The length of pipework between units was initially assumed as a nominal $10 \mathrm{~m}$.

Static head losses could be set to any value, but were assumed to be minimal, with default values of $0 \mathrm{~m}$ for suction heads and $0.3-3.0 \mathrm{~m}$ for outlet heads depending on the equipment type (raceway feed, $0.3 \mathrm{~m}$; centrifuge and lamellar harvester feed, $2 \mathrm{~m}$; conical settler feed, $3 \mathrm{~m}$; harvest return, $1 \mathrm{~m}$; and digestate return, $2 \mathrm{~m}$ ). The head for the supply pump to the digester was calculated from the required digester volume. 
Fluid viscosity and density of pumped fluids entering or exiting any one of the three areas of growth, harvesting or energy extraction could be set to any value. A data table was provided in the model giving values for fresh (43) or salt water (44) at ambient temperatures between 10-70 ${ }^{\circ} \mathrm{C}$. The physical properties of a microalgal suspension vary with concentration and may influence subsequent treatment and handling. A $1-2 \%$ suspension is milk-like (45) with a viscosity of 1.1-1.7 mPa-s similar to that of water $(46,47)$. Algal suspensions behave as Newtonian fluids at concentrations up to $4-8 \%$ depending on species $(47,48)$. Differences in viscosity in low concentration algal suspensions $(<5 \%)$ are not considered significant for the design and operation of algal growth systems (46). Default values for all sections of the model were therefore set at the fresh water values, as the vast majority of materials pumped and mixed were low-concentration algal suspensions

\subsubsection{Harvesting}

The model was originally developed with one harvesting unit for which the concentration factor, percentage recovery and energy input $\left(\mathrm{kWh} \mathrm{m}^{-3}\right)$ could be varied. This approach was adopted as the energy requirement for harvesting ranges widely depending on the method used, and a wide variety of technologies are applicable (49).The flow volumes and concentration of microalgae exiting the raceway and entering the harvesting system were calculated from the raceway volume and hydraulic retention time (HRT) and the biomass yield. The flow $\left(\mathrm{m}^{3} \mathrm{hr}^{-1}\right)$ and microalgal concentration (\% dry weight) leaving the harvesting unit were calculated from the chosen concentration factor and percentage recovery.

The model was subsequently modified to include multiple harvesting units and to allow varying flocculant doses and mixing energies.

\subsubsection{Anaerobic digestion}

Completely Stirred Tank Reactor (CSTR) digesters are widely used to treat wastes with up to $10 \%$ solids (50). They often operate mesophilically, with HRTs of about 20 days $(51,52)$. The CSTR digester design was therefore selected as suitable for handling microalgal biomass suspensions.

\subsubsection{Digester volume and dimensions}

There are many shapes of digester, but a vertical cylindrical tank design is the most common in the UK and USA (53) and was adopted here. Tank depth was taken to be equal to its diameter (54), and thus the surface area of the different sections of digester (top, bottom and sides) could 
be calculated for heat loss estimation. The digester volume $\left(\mathrm{m}^{3}\right)$ was calculated from the daily flow rate from the harvesting system $\left(\mathrm{m}^{3} \mathrm{day}^{-1}\right)$ and the digester HRT (days).

\subsubsection{Heating}

Although anaerobic digestion can occur at ambient temperatures the process is slow, and digesters are typically heated to enhance biogas production $(51,55)$. The digester temperature could be set to any value between $10-70{ }^{\circ} \mathrm{C}$. Default temperatures of 35 and $55^{\circ} \mathrm{C}$ were assumed for mesophilic and thermophilic digestion.

Heat energy is required not only to raise the feedstock temperature, but also to replace losses through the walls, roof and base of the digester. The heat required was calculated as follows:

Equation 11 Heat loss $\left(\mathrm{kJ} \mathrm{s}^{-1}\right)$

$$
\mathrm{H}_{\mathrm{l}}=\mathrm{UA} \Delta \mathrm{T}
$$

Equation 12 Initial Heating of Feedstock $\left(\mathrm{kJ} \mathrm{s}^{-1}\right)$

$$
\mathrm{H}=\mathrm{C}_{\mathrm{p}} \mathrm{Q} \Delta \mathrm{T}
$$

Equation 13 Total Heat Requirement $\left(\mathrm{kJ} \mathrm{s}^{-1}\right)$

$$
\mathrm{H}_{\mathrm{t}}=\mathrm{H}_{\mathrm{l}}+\mathrm{H}
$$

where $\mathrm{T}$ is temperature (degree $\mathrm{K}$ ), $\mathrm{C}_{\mathrm{p}}$ is specific heat $\mathrm{kJ} \mathrm{kg}^{-3} \mathrm{~K}^{-1}$, $\mathrm{Q}$ is volumetric flow rate $\mathrm{m}^{3} \mathrm{~s}^{-1}$ and $\mathrm{U}$ is heat transfer coefficient $\mathrm{W} \mathrm{m}^{-2} \mathrm{~K}^{-1}$.

Heat transfer coefficients $\mathrm{U}$ for digesters range from 0.3-5.2 $\mathrm{W} \mathrm{m}^{-2} \mathrm{~K}^{-1}(56)$ with typical values of $2 \mathrm{~W} \mathrm{~m}^{-2} \mathrm{~K}^{-1}$ (57). A digester with $100 \mathrm{~mm}$ of insulation can have a heat transfer coefficient of $0.35 \mathrm{~W} \mathrm{~m}^{-2} \mathrm{~K}^{-1}(58)$. The model allows selection of any heat transfer coefficient values for the top, sides and base, with a default value of $0.35 \mathrm{~W} \mathrm{~m}^{-2} \mathrm{~K}^{-1}$.

\subsubsection{Mixing}

It is widely accepted that digesters need to be mixed to distribute enzymes and microorganisms and prevent settling of solid particles $(56,59)$. Continuous mixing was assumed, and a number of approaches to estimating mixing energy were considered. 
The turbulent flow in impeller mixed systems is "inherently complex and not amenable to rigorous theoretical treatment" (42) with "no single design parameter that can be applied to all systems" (60). The root-mean square velocity gradient (G), which is a function of energy per unit volume and viscosity, has been suggested as a measure of mixing, with a value between 50 $80 \mathrm{~s}^{-1}$ being proposed as adequate for digester mixing (61). The degree of mixing in anaerobic digesters has also been related to power delivered per unit volume of the digester $(53,59,60)$, and for low viscosity Newtonian liquid feedstocks this is probably adequate. The model therefore used a simple power-per-unit-volume that can be set to any value.

Mixing power inputs are typically taken as $5-8 \mathrm{~W} \mathrm{~m}^{-3}(53,56)$, although a recent study found that lower values of $0.5-4 \mathrm{~W} \mathrm{~m}^{-3}$ may be sufficient (59). These recommendations are below the 'rule of thumb' for blending of 40-100 $\mathrm{W} \mathrm{m}^{-3}$ (54) and considerably below the average power consumption for mixed biochemical vessels of $1-2 \mathrm{~kW} \mathrm{~m}^{-3}$ (62), but match those recently reported by the AD industry (Methanogen, personal communication, 2013). A default value of 5 $\mathrm{W} \mathrm{m} \mathrm{m}^{-3}$ for digester mixing was therefore used.

A Rushton turbine was assumed as these are frequently used for industrial fermentation at low to medium viscosities. A power number of 5.5 (62) and an impeller diameter of $0.3 \mathrm{x}$ tank diameter (54) were taken as default values; other values can be used. The speed of the impeller and the mixing Reynolds number were calculated using standard mixing power equations (62, $63)$. Root-mean square velocity gradient was also calculated. This additional data can be used to check that the flow is turbulent and used for comparison, if required, with alternative mixing measurements

\subsection{Validation and calibration}

The anaerobic digestion section of the model was validated against an existing $\mathrm{AD}$ model (55).

A default maximum loading rate of $6 \mathrm{~kg} \mathrm{VS} \mathrm{m}^{-3}$ day $^{-1}(64)$ was assumed. If the maximum rate is exceeded a warning message appears and the digester volume is automatically increased to reduce the loading rate. All scenarios considered in the current research were within this assumed maximum loading rate.

A mass balance was carried out on the system and on the inflows and outflows of the digester. If the system is out of balance an error message appears. In all the runs discussed the system balanced. 


\section{Scenario modelling}

The model was used to investigate the viability of a number of options and scenarios in terms of energy output, and to identify the most critical parameters affecting net energy production. The model was initially applied to examine the effect of raceway dimensions on head losses, in order to establish whether a raceway of 1 hectare was feasible; and then used to study energy input relative to biomass energy production and outgassing. A number of options were then examined involving operation at different digester temperatures, $\mathrm{CO}_{2}$ concentrations in the gas supply and hydraulic retention times in both the digester and raceway. The relative importance of these parameters was thus determined.

\subsection{Head loss in raceways}

The model was first used to look at the effect of channel width and length on head losses in raceways with areas ranging from $103 \mathrm{~m}^{2}$, typical of pilot-scale plant, to 1 hectare, representing a likely size for commercial-scale operation (65).

Output head loss results from the model are shown in Table 1. The maximum head difference recommended by a paddlewheel manufacturer for commercial algal raceways is $0.076 \mathrm{~m}$ (Waterwheel Factory Inc. private communication, 2010) and thus a 1-hectare lined raceway appears to be possible.

Halving the width of a $219 \mathrm{~m}$ long raceway has little effect on head loss, but halving the length of a $20 \mathrm{~m}$ wide raceway has a significant effect, with head losses reduced from 0.052 to 0.041 $\mathrm{m}$. A $20 \mathrm{~m}$ wide raceway $109 \mathrm{~m}$ long has a similar head loss to a raceway $50 \mathrm{~m}$ long and only 1 $\mathrm{m}$ wide, confirming that raceways should be as wide as possible. 
Table 1. Head loss in raceways of different dimensions

\begin{tabular}{lccccc}
\hline Parameter & Unit & \multicolumn{4}{c}{ Value } \\
\hline Raceway channel length & $\mathrm{m}$ & 50 & 219 & 219 & 109 \\
Raceway channel width & $\mathrm{m}$ & 1 & 20 & 10 & 20 \\
Area & $\mathrm{m}^{2}$ & 103 & 10017 & 4694 & 5617 \\
Head & $\mathrm{m}$ & 0.040 & 0.052 & 0.052 & 0.041 \\
\hline
\end{tabular}

\subsection{Energy input relative to biomass energy production and outgassing in a raceway}

The model was used to study the energy inputs and potential output for a raceway consisting of two $50 \mathrm{~m}$ long and $1 \mathrm{~m}$ wide channels, similar to an experimental raceway used in Spain (39). A photosynthetic yield of $1.5 \%$ was assumed, equivalent to an average biomass yield of $13 \mathrm{~g} \mathrm{~m}^{2}$ day $^{-1}$.

\subsubsection{Effect of depth and velocity on energy ratio}

The effect of average fluid velocities from 0.15 to $0.45 \mathrm{~m} \mathrm{~s}^{-1}$ and raceway depths from 0.15 to $0.45 \mathrm{~m}$ on the ratio of energy input to potential biomass energy output was considered, and the results are shown in Figure 2a. The biomass energy output of the raceway was estimated at 8.48 $\mathrm{kWh}$ day $^{-1}$. Energy input increases with increasing depth and fluid velocity: a $0.45 \mathrm{~m}$ deep raceway flowing at $0.45 \mathrm{~m} \mathrm{~s}^{-1}$ was estimated to use $4 \mathrm{kWh} \mathrm{day}^{-1}$, or $48 \%$ of the energy potentially available in the microalgal biomass, confirming that depths and fluid velocities should be minimised $(65,66)$. At depths $<0.15 \mathrm{~m}$, however, it may be difficult to achieve sufficiently even grading of the raceway bottom to ensure consistent flow around the entire raceway (34); mixing problems and temperature variation may also occur at depths $<0.25 \mathrm{~m}$ (67). There appear to be no energy balance advantages to raceways deeper than $0.3 \mathrm{~m}$ or flowing faster than $0.3 \mathrm{~m} \mathrm{~s}^{-1}$. The typical raceway depths of $0.2-0.3 \mathrm{~m}(12,67-69)$ and velocities of $0.15-0.3 \mathrm{~m} \mathrm{~s}^{-1}(65,66)$ are therefore appropriate. 

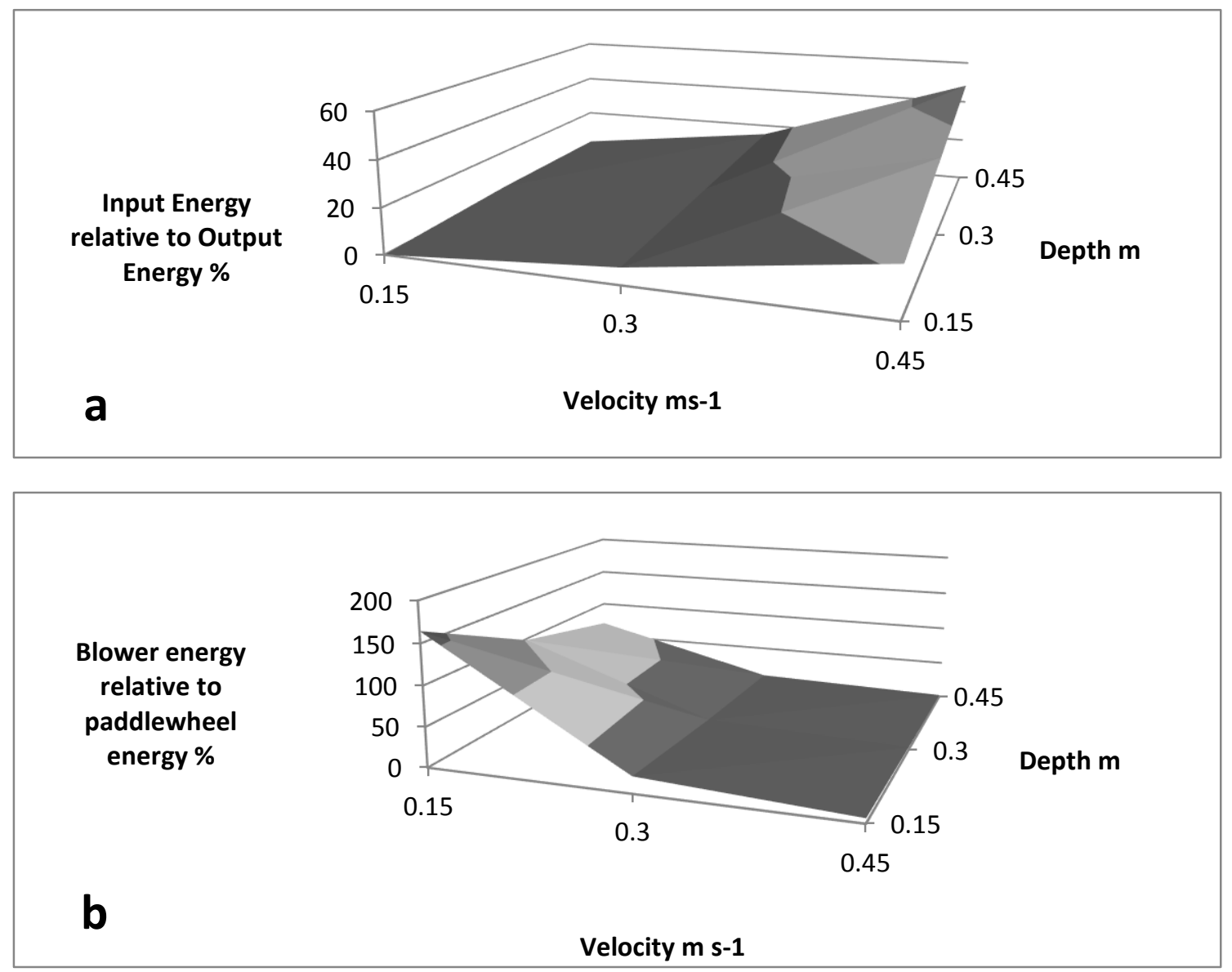

Figure 2 Effect of fluid velocity and raceway depth on the ratio of energy input to potential biomass energy output and on blower to paddlewheel energy

(a) Ratio of energy input to potential biomass energy output

(b) Ratio of blower to paddlewheel energy

The ratio of blower to paddlewheel input energy is shown in Figure 2b. Blower energy of 0.1 $\mathrm{kWh}$ day $^{-1}$ was the main energy input into a raceway at $0.15 \mathrm{~m}$ depth flowing at $0.15 \mathrm{~m} \mathrm{~s}^{-1}$. The ratio increases with reducing depth and fluid velocity: this was the result of reducing paddlewheel energy rather than increases in blower energy.

\subsubsection{Effect of depth and velocity on outgassing of $\mathrm{CO}_{2}$ in raceways}

The model was used to look at the effect on $\mathrm{CO}_{2}$ outgassing of average fluid velocities from $0.15-0.45 \mathrm{~m} \mathrm{~s}^{-1}$ and raceway depths from $0.15-0.45 \mathrm{~m}$, at different channel widths (1, 5 or $\left.10 \mathrm{~m}\right)$ and lengths (50 or $100 \mathrm{~m}$ ). 
The results in Table 2 show that increasing the fluid velocity from 0.15 to $0.45 \mathrm{~m} \mathrm{~s}^{-1}$ at the same depth $(0.3 \mathrm{~m})$ reduces relative outgassing, despite the increased energy input. This appears to be due to the shorter residence time in the channels before the flow returns to the gas exchange sump.

Reducing the depth from $0.45 \mathrm{~m}$ to $0.15 \mathrm{~m}$ at the same fluid velocity $\left(0.3 \mathrm{~m} \mathrm{~s}^{-1}\right)$ increases the amount of $\mathrm{CO}_{2}$ outgassed relative to the amount required for algal growth from $4 \%$ to $34 \%$, confirming the suggestion of Lundquist et al (67) that high rates of carbon dioxide outgassing may occur at depths $<0.25 \mathrm{~m}$. The ratio of energy input to output was lower in the shallower raceway, however, and thus if the $\mathrm{CO}_{2}$ was from a waste emission source, with little embodied energy or cost, raceways shallower than $0.25 \mathrm{~m}$ could be energetically and economically advantageous.

Table 2 Effect of flow velocity and depth and of channel width and length on outgassing and energy ratio in raceways

\begin{tabular}{lcccccccc}
\hline Parameter & Unit & Value & & & & \\
\hline Depth & $\mathrm{m}$ & 0.3 & 0.3 & 0.3 & 0.15 & 0.45 & - \\
Velocity & $\mathrm{m} \mathrm{s}^{-1}$ & 0.15 & 0.3 & 0.45 & 0.3 & 0.3 & - \\
Ratio input energy to output & $\%$ & 2.4 & 11.1 & 34.5 & 7.1 & 15.2 & - \\
$\mathrm{CO}_{2}$ outgassed to growth requirement & $\%$ & 11 & 8 & 7 & 34 & 4 & - \\
\hline Width & $\mathrm{m}$ & 1 & 5 & 10 & 1 & 5 & 10 \\
Length & $\mathrm{m}$ & 50 & 50 & 50 & 100 & 100 & 100 \\
Ratio input energy to output & $\%$ & 11.1 & 9.3 & 8.3 & 7.3 & 6.2 & 5.8 \\
$\mathrm{CO}_{2}$ outgassed to growth requirement & $\%$ & 8 & 9 & 10 & 17 & 18 & 19 \\
\hline
\end{tabular}

The results in Table 2 show that the energy return improves with increasing raceway width and length. $\mathrm{CO}_{2}$ outgassing relative to the amount of $\mathrm{CO}_{2}$ required for algal growth increases with increasing channel width and length: this was due to the longer residence time in the raceway channels before the flow returns to the gas exchange sump. The outgassing of $\mathrm{CO}_{2}$ will be more significant in large raceways. In a raceway of $\sim 1$ hectare $(219 \mathrm{~m}$ by $20 \mathrm{~m})$, the model predicts that losses due to outgassing are equivalent to $45 \%$ of the amount required for algal growth needs. 
Figure 3 shows the effect of raceway width on the ratio of blower energy to mixing energy, and on the ratio of raceway energy inputs to biomass energy output. The ratio of blower energy to mixing energy in the raceway increases with increasing width, but the ratio of input to output energy decreases with increasing width. It would thus appear that raceways should be as wide as practicable. The results thus support the recommendation from the US Energy Department study (34) of a length to width ratio of 11 to 1 for a raceway of $\sim 1$ hectare.

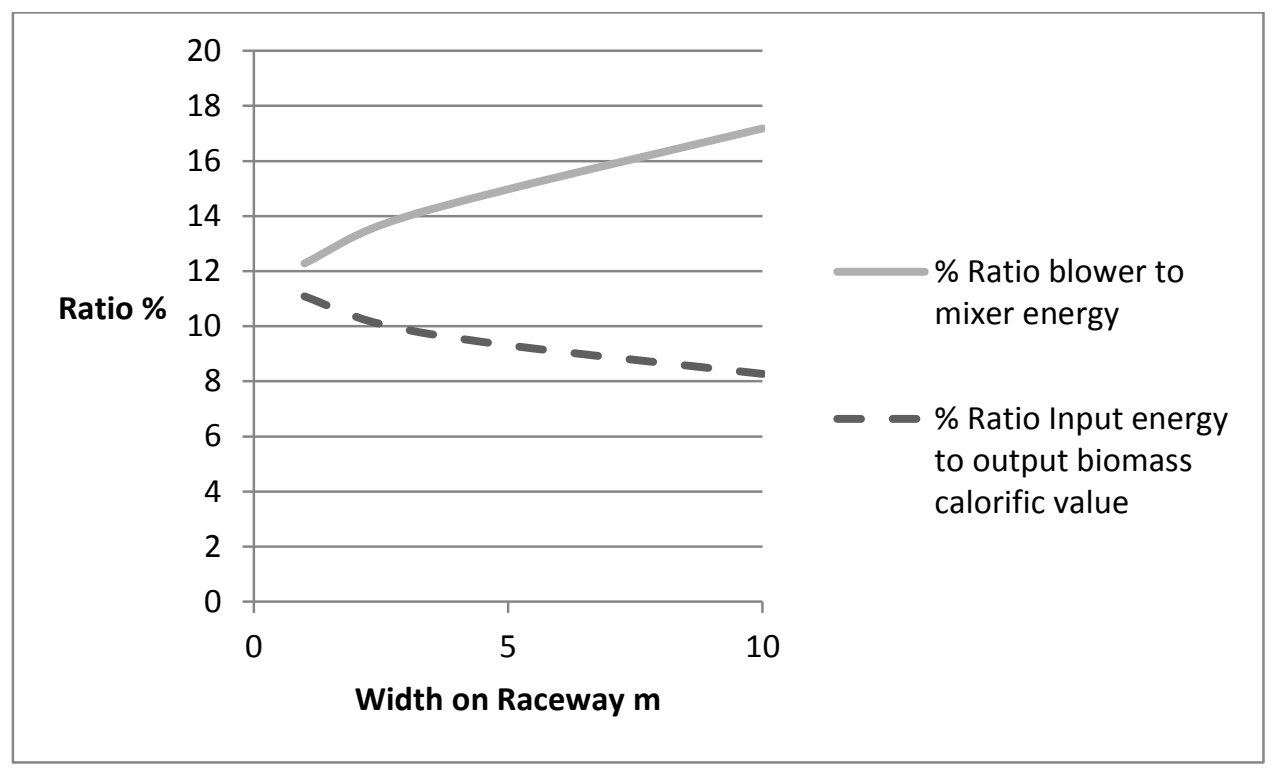

Figure 3 Effect of width on energy inputs in raceways

\subsubsection{Effect of microalgal photosynthetic efficiency on outgassing and energy ratio in raceways}

The effects of variations in microalgal photosynthetic efficiency on outgassing and energy ratio in a raceway are shown in Table 3. Photosynthetic efficiency has a negligible effect on the amount of $\mathrm{CO}_{2}$ outgassed relative to the amount of $\mathrm{CO}_{2}$ required for algal growth. 
Table 3 Effect of microalgal photosynthetic efficiency on outgassing and energy ratio in raceways

\begin{tabular}{lllll}
\hline Parameter & Unit & Value & \\
\hline Photosynthetic Efficiency & $\%$ & 1.5 & 3 & 4.5 \\
Ratio input energy to output & $\%$ & 11.1 & 6.1 & 4.5 \\
Ratio $\mathrm{CO}_{2}$ outgassed to growth requirement & $\%$ & 8 & 8 & 8 \\
\hline
\end{tabular}

\subsection{Effect of selected process parameters on the concentration factor required to achieve an EROOI of 1}

The model was used to estimate the concentration factor required to achieve an energy return on operational energy invested (EROOI) of 1 for a variety of process options. In general the higher the harvesting concentration factor, the greater the energy input needed to achieve it $(47,70$, 71), and process options with the lowest concentration factors will thus have the highest probability of achieving a positive energy balance. The concentration factor to achieve an EROOI of 1 was therefore used as a measure of the potential energy efficiency for a range of process options. For this particular purpose, equipment efficiencies and carbon conversion were taken as $100 \%$ and the energy input for harvesting was assumed to be zero.

\subsubsection{Effect of raceway dimensions}

The model was used to look at the effect of raceway width and depth on the concentration factor required to achieve an EROOI of 1.

Table 4 shows the required concentration factor for various raceway dimensions. The small raceway $\left(103 \mathrm{~m}^{2}\right)$ required a higher concentration factor than the larger raceways. Halving the length or width of the largest raceway had little effect on the required concentration factor. Variation of raceway dimensions to give areas of 0.5-1 ha with widths of 10-20 m made only negligible differences to the required concentration factor, and this implies that dimensions of raceways of this size can be varied to suit land and operational constraints with minimal effect on the overall energy balance ratio. A raceway area of $\sim 1$ hectare (channels $20 \mathrm{~m}$ wide and 219 $\mathrm{m}$ long) was assumed in all subsequent scenarios used in this work. 
Table 4 Concentration factor to achieve an EROOI equal to 1 for various raceway dimensions

\begin{tabular}{lccccc}
\hline Parameter & Unit & Value & & \\
\hline Raceway channel length & $\mathrm{m}$ & 50 & 219 & 219 & 109 \\
Raceway channel width & $\mathrm{m}$ & 1 & 20 & 10 & 20 \\
Estimated Area & $\mathrm{m}^{2}$ & 103 & 10017 & 4694 & 5617 \\
Concentration Factor & - & 30 & 22 & 22 & 22 \\
\hline
\end{tabular}

\subsubsection{Concentration factor to achieve an EROOI equal to 1 for various process options}

The model was used to determine the concentration factor associated with an EROOI of 1 for a 'benchmark' case (scenario H) and a range of alternative process conditions. The parameters for the benchmark case are shown in Table 5. The various alternative scenarios, with a brief description of how they vary from the benchmark, are shown in Table 6 with the corresponding concentration factors obtained from the modelling. The scenarios examined were not all intended to represent realistic options, but were selected in order to establish the likely operating range for modelling purposes, and to provide a framework for more detailed scenario modelling in future. Specific assumptions associated with each scenario are further described and discussed in the sections below. 
Table 5 Assumptions for 3\% PE, $25 \mathrm{~g} \mathrm{~m}^{-2}$ day $^{-1}$ benchmark

\begin{tabular}{llr}
\hline Parameter & Unit & Value \\
\hline Environmental & & \\
Solar insolation & $\mathrm{kWh} \mathrm{m}^{-2}$ year $^{-1}$ & 2000 \\
Photosynthetic efficiency (PE) & \multicolumn{1}{c}{${ }^{\circ} \mathrm{C}$} & 3 \\
Ambient temperature & & 20 \\
\hline Raceway & $\mathrm{m}^{2}$ & 10017 \\
Area & $\mathrm{m}$ & 0.3 \\
Depth & $\mathrm{ms}^{-1}$ & 0.3 \\
Average fluid velocity & $\mathrm{days}^{1}$ & 2 \\
Hydraulic retention time (HRT) & $\mathrm{g}(\mathrm{dw}) \mathrm{l}^{-1}$ & 0.17 \\
Algal Concentration & &
\end{tabular}

Gaseous exchange

$\mathrm{CO}_{2}$ concentration in supply

$\% \quad 12$

\section{Harvesting}

$\begin{array}{lll}\text { Algal harvesting recovery } & \% & 100\end{array}$

Concentration factor $\quad 22$

Anaerobic Digestion

$\%$ of "Buswell" estimated $\mathrm{CH}_{4}$ yield $\quad \% \quad 100$

Hydraulic retention time (HRT) days 20

Mesophilic digester temperature $\quad{ }^{\circ} \mathrm{C} \quad 35$

Equipment efficiencies

$\begin{array}{lll}\text { Paddlewheel efficiency } & \% & 100\end{array}$

$\begin{array}{lll}\text { Gas transfer efficiency } & \% & 80\end{array}$

$\begin{array}{lll}\text { Blower efficiency } & \% & 100\end{array}$

$\begin{array}{lll}\text { Pump efficiency } & \% & 100\end{array}$

Percentage heat recovery $\%$

$\begin{array}{lll}\text { Heater efficiency } & \% & 100\end{array}$

$\begin{array}{lll}\text { Mixer efficiency } & \% & 100\end{array}$ 
Table 6 Concentration factor to achieve an EROOI equal to 1 for various process scenarios

\begin{tabular}{|c|c|c|}
\hline Scenario & Assumptions & $\begin{array}{c}\text { Concentration } \\
\text { Factor }\end{array}$ \\
\hline $\bar{A}$ & Maximum theoretical PE (11\%) & 6 \\
\hline B & 4 day raceway HRT $3 \%$ PE & 11 \\
\hline $\mathrm{C}$ & Reduced depth $0.15 \mathrm{~m}$ & 11 \\
\hline $\mathrm{D}$ & 10 day HRT in anaerobic digester & 20 \\
\hline $\mathrm{E}$ & Pure $\mathrm{CO}_{2}$ used for carbonation sump gas supply & 21 \\
\hline $\mathrm{F}$ & Reduced raceway velocity $0.15 \mathrm{~ms}^{-1}$ & 21 \\
\hline G & Reduced raceway mixing time 12 hours & 21 \\
\hline$\underline{\mathbf{H}}$ & BENCHMARK 3\% PE $25 \mathrm{~g} \mathrm{~m}^{-2} \mathrm{day}^{-1}$ & $\underline{22}$ \\
\hline I & $6 \% \mathrm{CO}_{2}$ used for carbonation sump gas supply & 22 \\
\hline $\mathrm{J}$ & 4 Day Raceway HRT $1.5 \%$ PE & 22 \\
\hline $\mathrm{K}$ & $60 \%$ harvest efficiency & 23 \\
\hline $\mathrm{L}$ & 30 day HRT in anaerobic digester & 23 \\
\hline M & Typical Equipment efficiencies & 27 \\
\hline $\mathrm{N}$ & Reduced Insulation $2 \mathrm{~W} \mathrm{~m}^{-2} \mathrm{~K}^{-1}$ & 28 \\
\hline $\mathrm{O}$ & $60 \%$ of predicted maximum $\mathrm{CH}_{4}$ yield by Buswell equation & 38 \\
\hline $\mathrm{P}$ & Lower Yield PE 1.5\% & 45 \\
\hline Q & Thermophilic anaerobic digestion $55^{\circ} \mathrm{C}$ & 48 \\
\hline $\mathrm{R}$ & Raceway located in Southampton with 3\% PE Yield & 73 \\
\hline$S$ & Raceway located in Southampton with $1.5 \%$ PE Yield & 158 \\
\hline $\mathrm{T}$ & Air used for carbonation sump gas supply $\left(0.038 \% \mathrm{CO}_{2}\right)$ & $905>$ \\
\hline
\end{tabular}

\subsubsection{Benchmark case}

Scenario $\mathrm{H}$ with $3 \% \mathrm{PE}$ at solar insolation of $2000 \mathrm{kWh} \mathrm{m}^{-2}$ day $^{-1}$ and average temperature of $20{ }^{\circ} \mathrm{C}$ was selected as the benchmark. The parameters of the benchmark are shown in Table 5 , while key outputs are shown in Table 7. 
Table 7 Model output for benchmark

\begin{tabular}{|c|c|c|}
\hline Outputs & Unit & Value \\
\hline Concentration factor & & 22 \\
\hline Biomass yield & $\mathrm{g} \mathrm{m}^{-2}$ day $^{-1}$ & 25 \\
\hline Algal concentration in raceway & & $0.017 \%$ \\
\hline Biomass calorific yield & $\mathrm{kWh} \mathrm{day}^{-1}$ & 1646 \\
\hline$\%$ Algae DW concentration in feed to $\mathrm{AD}$ & & $0.36 \%$ \\
\hline Calorific value of $\mathrm{CH}_{4}$ production & $\mathrm{kWh}_{\text {day }}{ }^{-1}$ & 1559 \\
\hline \multicolumn{3}{|l|}{ Energy Inputs } \\
\hline Paddlewheel mixing of raceway & $\mathrm{kWh}_{\text {day }}{ }^{-1}$ & 21.83 \\
\hline Supply pump energy & $\mathrm{kWh} \mathrm{day}^{-1}$ & 3.04 \\
\hline Harvest supply pump energy & $\mathrm{kWh}_{\text {day }}{ }^{-1}$ & 10.15 \\
\hline AD supply pump energy & $\mathrm{kWh} \mathrm{day}^{-1}$ & 2.36 \\
\hline Harvest 'return' pump energy & $\mathrm{kWh} \mathrm{day}^{-1}$ & 5.54 \\
\hline Digestate 'return' pump energy & $\mathrm{kWh}_{\text {day }}{ }^{-1}$ & 0.39 \\
\hline Total pumping energy & $\mathrm{kWh} \mathrm{day}^{-1}$ & 21.48 \\
\hline Blower energy & $\mathrm{kWh}_{\text {day }}{ }^{-1}$ & 22.79 \\
\hline $\mathrm{AD}$ reactor volume & $\mathrm{m}^{3}$ & 1420.7 \\
\hline AD heating energy & $\mathrm{kWh}_{\text {day }}{ }^{-1}$ & 1322.76 \\
\hline AD mixing & $\mathrm{kWh}_{\text {day }}{ }^{-1}$ & 170.44 \\
\hline Total AD input energy & $\mathrm{kWh}_{\text {day }}{ }^{-1}$ & 1493.20 \\
\hline Total operational energy input & $\mathrm{kWh}_{\text {day }}{ }^{-1}$ & 1559.30 \\
\hline Energy return on operational energy invested & - & 1.0 \\
\hline
\end{tabular}

The energy inputs in the benchmark case for paddlewheel mixing, pumping and the blower to supply $\mathrm{CO}_{2}$ in flue gas are of a similar order at $21.83,21.48$ and $22.79 \mathrm{kWh} \mathrm{day}^{-1}$ respectively: each was equivalent to $1.4-1.5 \%$ of the energy potentially available in the methane produced. The major energy inputs are in the heating and mixing in the anaerobic digester, using $84.8 \%$ and $10.9 \%$ of the energy of methane produced. The benchmark case assumes no heat recovery, however, and this would significantly reduce the required heating energy. The feed concentration of microalgal VS to the digester of $0.36 \%$ was lower than typically applied in CSTR reactors. Increasing the feed VS concentration to $1 \%$ reduces the mixing and heating energy by $64 \%$ and $63 \%$, giving a total reduction for $\mathrm{AD}$ of $551 \mathrm{kWh} \mathrm{day}^{-1}$. This was equivalent to $0.13 \mathrm{kWh} \mathrm{m}^{-3}$ of harvesting energy, and if the additional energy input to the harvesting 
system required to achieve the higher output concentration were less than this, there could be an improvement in the net energy output.

\subsection{4 $\quad \mathrm{CO}_{2}$ concentration}

The highest concentration factor required and the biggest deviation from the benchmark case was with the use of atmospheric air as a source of carbon (scenario T) rather than flue gas containing $12 \% \mathrm{CO}_{2}$. At the required concentration factor of 900 an algal suspension of $15 \%$ DW microalgae would be required, which may no longer be fluid. The energy to provide air to the medium was far greater than that in the algal biomass, and the net energy return was massively negative with an EROOI of 0.002. Bubbling air into a raceway as a source of $\mathrm{CO}_{2}$ was clearly not energetically viable.

Halving the $\mathrm{CO}_{2}$ concentration of flue gas to $6 \%$ (scenario I) had little effect on the concentration factor compared to that for the benchmark value of $12 \% \mathrm{CO}_{2}$. Flue gas typically has a $\mathrm{CO}_{2}$ content of $6-13 \%$, and variation between these values has little effect on the required concentration factor.

Using pure $\mathrm{CO}_{2}$ (scenario $\mathrm{E}$ ) marginally improved the required concentration factor, from 22 to 21. The energy to produce and transport pure $\mathrm{CO}_{2}$, however, was likely to be considerably greater than the reduction achieved by providing pure $\mathrm{CO}_{2}$ instead of flue gas.

\subsubsection{Effect of factors increasing microalgal concentration}

Scenarios A to C considered the effect of factors that could increase the concentration of the microalgal culture, by increasing the maximum theoretical PE yield to $11 \%$ (scenario A), implementing a 4-day HRT in the raceway (scenario B), or reducing the raceway depth to 0.15 $\mathrm{m}$ (scenario C). All these factors increased the concentration of the algal suspension entering the harvester, thus reducing the concentration factor required to achieve an EROOI of 1. Increasing yield reduces the required concentration factor, but yields above 3\% PE may not be achievable in practice $(16,72)$.

Increasing the raceway HRT to 4 days may also not be practicable. Raceways appear to produce stable cultures at 2 to 3 days HRT (34), but 'crashes' regularly occur at 4 days (73). Zamalloa, Vulsteke (74) recommended a HRT of 2 days. 
Reducing the depth to $0.15 \mathrm{~m}$ may also not be practicable due to problems in grading the raceway bed (34). In this scenario, the head loss around the raceway was estimated at $0.082 \mathrm{~m}$, slightly greater than the maximum differential head recommended by a paddlewheel manufacturer and half the recommended maximum mean depth as suggested by Oswald (45).

\subsubsection{Effect of paddlewheel operation factors}

In scenario $\mathrm{F}$ the fluid velocity in the raceway was reduced to $0.15 \mathrm{~m} \mathrm{~s}^{-1}$ and in scenario $\mathrm{G}$ paddlewheel operation was reduced to 12 hours per day during daylight. Both scenarios had a similar effect on the required concentration factor, causing a reduction from 22 to 21 .

The suspension of paddlewheel mixing at night (scenario G) may not be practicable as without mixing the microalgae may settle to the bottom of the raceway. Reducing the fluid velocity in the raceway to $0.15 \mathrm{~m} \mathrm{~s}^{-1}$ (scenario $F$ ) reduced the paddlewheel input energy from 21.83 to 2.73 $\mathrm{kWh}_{\text {day }}{ }^{-1}$, but increased the required blower energy from 22.79 to $23.37 \mathrm{kWh} \mathrm{day}^{-1}$ due to the greater $\mathrm{CO}_{2}$ outgassing as a result of the longer circuit time. The reduction in paddlewheel energy was $\sim 10$-fold, but only corresponds to $1 \%$ of the total microalgal biogas process operation energy. However the fluid velocity should be minimised so far as is consistent with preventing microalgal sedimentation and providing regular exposure of the cells to light.

\subsubsection{Anaerobic digestion factors}

Scenarios D, L, N, O and Q involved changes to AD parameters. Thermophilic anaerobic digestion processes can potentially offer accelerated biochemical reactions and microbial growth rates with more rapid methane production and lower hydraulic retention times (75). Operation of the digester at $55{ }^{\circ} \mathrm{C}$ (scenario Q) gave a required concentration factor of 48 , reflecting the increased heat input. There was little difference, however, between required concentration factors for HRTs of 10 (scenario D), 20 (scenario H) and 30 days (scenario L) at 20, 22 and 23 respectively. It was thus probable that the increased energy input of thermophilic temperatures will not be offset by shorter HRTs and that mesophilic operation was the preferred option energetically. In all scenarios considered the main energy input for AD was heat. In thermophilic conditions $95 \%$ of the energy requirement was for heat, in good agreement with the $94 \%$ found in a practical study of a thermophilic pilot digester (76).

Increasing the heat transfer coefficient from 0.35 to $2 \mathrm{~W} \mathrm{~m}^{-2} \mathrm{~K}^{-1}$ by reducing the digester insulation (scenario $\mathrm{N}$ ) increased the concentration factor from 22 to 28 , a greater effect than that found for changes in HRT. A heat transfer coefficient of $2 \mathrm{~W} \mathrm{~m}^{-2} \mathrm{~K}^{-1}$ is typical of $25 \mathrm{~mm}$ of 
insulation on a steel vessel (77) and of many commercial AD plants $(78,79)$. The heat loss from the AD reactor with a heat transfer coefficient of $2 \mathrm{~W} \mathrm{~m}^{-2} \mathrm{~K}^{-1}$ was estimated at $0.35^{\circ} \mathrm{C}$, well below the maximum loss of $1{ }^{\circ} \mathrm{C}_{\text {day }}^{-1}$ recommended for the design and operation of agricultural digesters (52). The heat loss from a well-insulated digester $\left(0.35 \mathrm{~W} \mathrm{~m}^{-2} \mathrm{~K}^{-1}\right)$ was estimated at $0.05^{\circ} \mathrm{C} \mathrm{day}^{-1}$, however, with a corresponding reduction in the energy requirement for heating of over $23 \%$. Using the model, the reduction in heat loss for digester with a volume of $1000 \mathrm{~m}^{3}$ for a change in heat transfer coefficient from 2 to $0.35 \mathrm{~W} \mathrm{~m}^{-2} \mathrm{~K}^{-1}$ was calculated at $30.1 \mathrm{kWh} \mathrm{day}^{-1}$. This reduction in heat transfer coefficient could be achieved by increasing the depth of insulation from 0.025 to $0.1 \mathrm{~m}(58,77)$, and would require an additional $3.8 \mathrm{~m}^{3}$ of insulation for a $1000 \mathrm{~m}^{3}$ vertical-cylinder digester. Assuming an embodied energy for fibreglass of $269 \mathrm{kWh} \mathrm{m}^{-3}$, the additional embodied energy could be recovered in reduced heat loss in less than 34 days. These calculations strongly confirm the importance of controlling heat loss for an energy-efficient process.

Actual methane yields from the anaerobic digestion of microalgae are considerably below theoretical values. If the methane yield was reduced to $60 \%$ of the theoretical maximum (scenario $\mathrm{O}$ ), the required concentration factor increases from 22 to 38 . This was a smaller effect than that associated with increasing the temperature from 35 to $55^{\circ} \mathrm{C}$, but greater than increasing the HRT or reducing the insulation. Maximizing methane yield from algae will be vital for an energy efficient process. Strains with a lower biomass yield but a higher specific methane production in operational practice may have an energy balance advantage over higheryielding strains that are more recalcitrant.

\subsubsection{Climate conditions}

Scenarios $\mathrm{R}$ and $\mathrm{S}$ looked at the effect of siting the system in a location with an average temperature of $10{ }^{\circ} \mathrm{C}$ and insolation $1000 \mathrm{kWh} \mathrm{m}^{-2}$, similar to Southampton, UK. At $3 \% \mathrm{PE}$ (scenario R) the required concentration factor increased to 73 compared to 22 for the benchmark case (equivalent to the climatic conditions of typical target areas such as the south-west USA and south-west Africa). Microalgal growth rates are often reduced in lower temperatures (8083). A lower PE efficiency of $1.5 \%$ (scenario $\mathrm{S}$ ) was therefore assumed in addition to the average temperature of $10{ }^{\circ} \mathrm{C}$ and the estimated required concentration factor increased to 158 .

\subsubsection{Harvesting and equipment efficiencies}


Actual equipment energy efficiencies and harvesting recovery rates for microalgal biomass are less than $100 \%$. Scenarios $\mathrm{K}$ and $\mathrm{M}$ therefore looked at the effects of introducing more realistic typical values for process efficiency.

\subsubsection{Harvesting efficiency}

For harvesting by sedimentation, typical microalgal biomass recovery rates are 60\% (84). Adopting a reduced harvesting recovery rate of $60 \%$ (scenario K) marginally increased the required concentration factor, from 22 to 23 . The presence of microalgal biomass in the dilute stream exiting the harvesting system may not be a problem if it can be recycled to the growth system; but otherwise may represent an additional expense, a loss of resources and a potential waste management problem.

\subsubsection{Other equipment efficiencies}

Paddlewheels can be highly efficient and are showing considerable promise as hydropower converters at very low head differences (85), but figures quoted for paddlewheel efficiency in algal growth systems are low at 10 to $20 \%(25,65,66,86)$. Efficiencies of $40 \%$ have been suggested for optimised paddlewheel designs in raceways (87), and efficiencies of up to $75 \%$ have been found for advanced designs extracting energy from flows with low head differences (85). Methods of reducing the energy input for mixing microalgal raceways have not been extensively studied $(66,88,89)$ and it would appear that considerable improvements could be made to microalgal raceway paddlewheel design

In scenario $M$ the following efficiencies were assumed: paddlewheel 50\%; pump, mixer, heater and blower $80 \%$. These are at the upper end of typical values $(54,87)$.

The result was an increase in the concentration factor from 22 to 27 . This effect was less than that caused by reducing digester insulation, but as in scenario $\mathrm{N}$ the increased cost and embodied energy of providing more energy efficient systems may be recovered in reduced operational energy.

\subsubsection{Summary of scenario results}

Table 6 shows the concentration factors for all the scenarios considered, ranked in order with the lowest at the top. The lower the concentration factor the lower the potential harvesting energy and overall energy input, and the higher the potential energy return. 
The highest concentration factor required and the biggest deviation from the benchmark case was with the use of air (scenario $\mathrm{T}$ ) rather than flue gas. The lowest concentration factors required were for the maximum theoretical PE yield $11 \%$ (scenario A), a 4-day raceway HRT (scenario $\mathrm{B}$ ) or reducing the depth to $0.15 \mathrm{~m}$ (scenario $\mathrm{C}$ ). In the scenarios involving changes to $\mathrm{AD}$ parameters (scenarios $\mathrm{D}, \mathrm{L}, \mathrm{N}, \mathrm{O}$ and $\mathrm{Q}$ ) the highest concentration factor was associated with a thermophilic $\left(55^{\circ} \mathrm{C}\right)$ (scenario Q) rather than a mesophilic operating temperature $\left(35^{\circ} \mathrm{C}\right)$ (scenario $\mathrm{H}$ ). The scenarios involving climatic conditions gave the second and third highest required concentration factors and thus confirmed that production of microalgal biofuel in UK would be energetically challenging at best. Applying realistic values for equipment efficiencies (scenario M) increased the required concentration factor over that for the benchmark case; but the effect was less, for example, than from assuming a lower methane yield, indicating that improving the digestibility of microalgal biomass may be more critical to the success of the technology.

\section{Conclusions}

The current work used a mechanistic energy balance model for the anaerobic digestion of raceway-grown microalgal biomass with the aim of identifying the most critical parameters affecting net energy production, and investigating the potential viability of a range of idealised scenarios in terms of energy return on operational energy input.

The model was initially used to examine the influence of raceway parameters on performance: the results confirmed that typical raceway depths and velocities of $0.2-0.3 \mathrm{~m}$ and $0.15-0.3 \mathrm{~m} \mathrm{~s}^{-1}$ are appropriate. For a given raceway area wider channels are more efficient, and lined raceways of 1 ha appear to be feasible in energy terms.

The model was then used to determine the concentration factor required to achieve an EROOI of 1 for a range of alternative process conditions, in comparison with a benchmark case. Neither the benchmark case nor the alternative scenarios were intended to represent fully realistic conditions, since in most cases the efficiencies of carbon conversion and of process equipment (paddlewheel, pump, mixer, heater and blower) were taken as $100 \%$. The aim was rather to rule out certain options and identify other potentially feasible combinations, and to establish likely operating ranges for subsequent detailed modelling. Process options that were eliminated included the provision of supplementary carbon by bubbling atmospheric air into the sump: whatever its source, some form of $\mathrm{CO}_{2}$ enrichment will be required, making flue gas a potentially attractive option. Thermophilic digestion also appeared to be an unrealistic option in 
terms of energy return, although heat recovery and improved insulation could counteract this to some degree. As well as reduced insolation, greater requirements for digester heating also played a role in making the UK an unfavourable location. Options for ambient temperature digestion were not explored in the current study, but this topic is attracting considerable attention in the field of wastewater treatment. The results also confirmed that EROOI is likely to be very sensitive to methane yields, indicating that improvements in degradation and conversion efficiencies for microalgal biomass are key areas for research.

While the benchmark case used idealised process equipment efficiencies, adopting more realistic values had a relatively minor effect on EROOI. The same was true for a number of other factors in the alternative scenarios considered; while significant improvements were mainly related to changes in raceway volumetric productivity and/or algal biomass concentration. From this it may be concluded that the concentration achievable for a given energy input remains a useful assessment parameter, and that improved harvesting methods are a key component in improving energy performance.

The model itself evidently provides a powerful tool both for comparison of alternative system and process options, and potentially for the benchmarking of real schemes. The results of these initial studies indicate that energy-efficient production of microalgal biogas will require:

a) Favourable climatic conditions. The production of microalgal biofuel in the UK would be energetically challenging at best.

b) Achievement of 'reasonable yields' equivalent to $\sim 3 \%$ photosynthetic efficiency $\left(25 \mathrm{~g} \mathrm{~m}^{-2}\right.$ day $\left.^{-1}\right)$.

c) Low or no cost and embodied energy sources of $\mathrm{CO}_{2}$ and nutrients from flue gas and wastewater.

d) Mesophilic rather than thermophilic digestion.

e) Adequate conversion of the organic carbon to biogas $(\geq 60 \%)$.

Based on the above, subsequent studies should now be conducted using selected scenarios chosen to provide realistic and pragmatic operating conditions capable of delivering a positive energy balance from microalgal biogas production

\section{Acknowledgement}

Funding for this research was provided by EPSRC with additional support from the FP7 ALLGAS project 268208. 
1. Reed V. Algal Progress Report. Industrial Biotechnology. 2015

2015/02/01;11(1):3-5.

2. $\quad$ Service RF. Algae's Second Try. Science. $2011 ; 333: 1238-39$.

3. Harvey P, Abubakar AL, Xu Y, Bailey D, Milledge JJ, Swamy R, et al. The CO2 microalgae biorefinery: high value products from low value wastes using halophylic microalgae in the D-factory. Part 1: tackling cell harvesting. European Biomass Conference; Hamburg2014.

4. Milledge JJ, Heaven S. Methods of energy extraction from microalgal biomass: a review. Rev Environ Sci Biotechnol. 2014 2014/05/03;13(3):301-20. English.

5. Clarens AF, Nassau H, Resurreccion EP, White MA, Colosi LM. Environmental Impacts of Algae-Derived Biodiesel and Bioelectricity for Transportation. Environ Sci Technol. $2011 ; 45(17): 7554-60$.

6. Sills DL, Paramita V, Franke MJ, Johnson MC, Akabas TM, Greene CH, et al. Quantitative Uncertainty Analysis of Life Cycle Assessment for Algal Biofuel Production. Environ Sci Technol. 2012 2013/01/1 5;47(2):687-94.

7. Wiley PE, Campbell JE, McKuin B. Production of Biodiesel and Biogas from Algae: A Review of Process Train Options. Water Environ Res. 2011 Apr;83(4):32638. PubMed PMID: WOS:000289079900004. English.

8. Razon LF, Tan RR. Net energy analysis of the production of biodiesel and biogas from the microalgae: Haematococcus pluvialis and Nannochloropsis. Appl Energy. $2011 ; 88(10): 3507-14$.

9. Pfromm PH, Amanor-Boadu V, Nelson R. Sustainability of algae derived biodiesel: A mass balance approach. Bioresource Technology. 2011 Jan;102(2): 11 85-93. PubMed PMID: ISI:000286782700104. English. 10. Mulder K, Hagens NJ. Energy return on investment: toward a consistent framework. Ambio. 2008 Mar;37(2):74-9. PubMed PMID: 18488548. English.

11. Collet P, Hélias A, Lardon L, Steyer J-P, Bernard O. Recommendations for Life Cycle Assessment of algal fuels. Appl Energy. 2015 (0).

12. Garofalo R. Algae and aquatic biomass for a sustainable production of 2 nd generation biofuels. Deliverables 3.3 and 3.5 Lifecycle assessment and environmental assessment. AquaFUELs, 2011.

13. Stephenson AL, Kazamia E, Dennis JS, Howe CJ, Scott SA, Smith AG. Life-Cycle Assessment of Potential Algal Biodiesel Production in the United Kingdom: A Comparison of Raceways and Air-Lift Tubular Bioreactors. Energy \& Fuels. 2010;24 (7):4062-77.

14. Dunlop E. Aspen Tech webinar 2012 [16/05/2013]. Available from: http://www.panpacific.com.au/aspen.html.

15. Moody LF. Friction factors for pipe flow. Trans A S M E. 1944;66:671-84.

16. Milledge JJ. The potential yield of microalgal oil. Biofuels International 2010;4(1):44 5 .

17. Weyer KM, Bush DR, Darzins A, Willson BD. Theoretical Maximum Algal Oil Production. Bioenergy Research. 2010 Jun;3(2):204-13. PubMed PMID: ISI:000278541500012. English.

18. Williams PJIB, Laurens LML. Microalgae as biodiesel \& biomass feedstocks: Review \& analysis of the biochemistry, energetics \& economics. Energy \& Environmental Science. 2010;3(5):554-90.

19. Chisti Y. Biodiesel from microalgae. Biotechnol Adv. 2007;25:294 -306.

20. Grobbelaar JU. Factors governing algal growth in photobioreactors: the "open" versus "closed" debate. J Appl Phycol. 2009 Oct;21(5):489-92. PubMed PMID: ISI:000270339900002. English. 
21. IFRF. International Flame Research Foundation. Online Combustion Handbook. Method from Combustion File 242004.

22. Buswell AM, Mueller HF. Mechanism of Methane Fermentation. Industrial \& Engineering Chemistry. 1952;44(3):550-2.

23. Symons GE, Buswell AM. The Methane Fermentation of Carbohydrates 1,2. Journal of the American Chemical Society. 1933;55(5):2028-36.

24. BSI. Natural gas - Calculation of calorific values, density, relative density \& Wobbe index from composition. BS EN ISO 6976:20052005.

25. Putt R. Algae as a Biodiesel Feedstock:A Feasibility Assessment. Department of Chemical Engineering, Auburn University,Alabama, 2007.

26. Sheehan J, Dunahay T, Benemann J, Roessler, P. A Look Back at the US Department of Energy's Aquatic Species Program - Biodiesel from Algae. Golden, CO, USA: National Renewable Energy Laboratory NREL, 1998 7. Report No.: NREL/TP-580-24190.

27. McBride RC, Lopez S, Meenach C, Burnett M, A. LP, Nohilly F, et al. Contamination Management in Low Cost Open Algae Ponds for Biofuels Production Industrial Biotechnology. 2014;10(3):221-7.

28. Milledge JJ. The challenge of algal fuel : economic processing of the entire algal biomass. Condensed Matter -Materials Engineering Newsletter [Internet]. 2010; 1(6):[4-6 pp.]. Available from:

http://mse.mcmaster.ca/Condensed\%20Matter/January2010.pdf.

29. Chanson H. Hydraulics of Open Channel Flow. London: Arnold; 1999.

30. Cheng NS. Power-law index for velocity profiles in open channel flows. Adv Water Resour. 2007 Aug;30(8):1775-84. PubMed PMID: WOS:000247713700006. English.

31. Weissman JC, Goebel RP. Design and analysis of microalgal open pond systems for the purpose of producing fuels: A subcontract report. 1987 SERI/STR231-2840; Other: ON: DE87001164.

32. de Godos I, Mendoza JL, Acien FG, Molina E, Banks CJ, Heaven S, et al. Evaluation of carbon dioxide mass transfer in raceway reactors for microalgae culture using flue gases. Bioresour Technol. 2014 Feb;153:307-14. PubMed PMID: 24374031. Epub 2014/01/01. eng.

33. Rogers GFC, Mayhew YR. Engineering thermodynamics - work \& heat transfer. New York: Longman; 1992.

34. Weissman JC, Tillett DM, Goebel RP. Design and operation of an outdoor microalgae test facility. Golden, Colorado: SERI, 1989 SERI/STR-232-3569.

35. Mendoza JL, Granados MR, de Godos I, Acién FG, Molina E, Heaven S, et al. Oxygen transfer and evolution in microalgal culture in open raceways. Bioresource Technology. 2013 6//;137(0):188-95.

36. Cole TM, Wells SA. CE-QUAL-W2. A two dimensional, laterally averaged, hydrodynamic \& water quality model, Version 3.5: User Manual. Vicksburg MS: US Army Corps Engineers, 1995 Contract No.: EL-06-01.

37. Chin DA. Water-Quality Engineering in Natural Systems. Hoboken: Wiley; 2006.

38. Molina Grima E. Microalgal mass culture, key aspects in design open outdoor culture and photobioreactors. Biodiesel production from microalgae: science, engineering and economic evaluation; Almeria2011.

39. Mendoza JL, Granados MR, de Godos I, Acién FG, Molina E, Banks C, et al. Fluid-dynamic characterization of real-scale raceway reactors for microalgae production. Biomass and Bioenergy. 2013;54:267-75.

40. Sompech K, Chisti Y, Srinophakun T. Design of raceway ponds for producing microalgae. Biofuels. 2012 2012/07/01;3(4):387-97. 
41. James SC, Boriah V. Modeling Algae Growth in an Open-Channel Raceway. Journal of Computational Biology. 2010 Jul;17(7):895-906. PubMed PMID:

ISI:000279976800003. English.

42. Coulson JM, Richardson JF. Coulson \& Richardson's Chemical engineering . Fluid Flow, Heat Transfer and Mass Transfer. 6 ed. Oxford: Elsevier; 1999.

43. Kestin J, Sokolov M, Wakeham WA. Viscosity of liquid water in the range -8 to $150{ }^{\circ} \mathrm{C}$. Journal of Physical and Chemical Reference Data. 1978;7(3):941-8.

44. El-Dessouky HT, Ettouney HM. Fundamentals of Salt Water Desalination Amsterdam: Elsevier; 2002.

45. Oswald WJ. Large-scale algal culture systems (engineering aspects). In: Borowitzka MA, Borowitzka LJ, editors. Micro-algal Biotechnology. Cambridge: Cambridge University Press; 1988.

46. Adesanya VO, Vadillo DC, Mackley MR. The rheological characterization of algae suspensions for the production of biofuels. J Rheol. 2012 Jul;56(4):925-39. PubMed PMID: WOS:000304305700011. English.

47. Bolhouse AM. Rheology of Algae slurries: University of Texas; 2010.

48. Wileman A, Ozkan A, Berberoglu H. Rheological properties of algae slurries for minimizing harvesting energy requirements in biofuel production. Bioresource Technology. 2012 Jan;104:432-9. PubMed PMID: WOS:000301155800058. English. 49. Milledge JJ, Heaven S. A review of the harvesting of micro-algae for biofuel production. Reviews in Environmental Science and Biotechnology. 2013;12(2):16578.

50. Wilkie AC. Effect of Ambient Temperature on the Energy Balance of Anaerobic Digestion Plants. Dairy Manure Conference; Cornell University2005. p. 301-12. 51. Rittmann BE, McCarty PL. Environmental biotechnology: principles and applications. Singapore: McGraw-Hill; 2001.

52. Persson SPE, Bartlett HD, Branding AE, Regan RW. Agricultural anaerobic digesters. Pennsylvania State University, 1979.

53. Christodoulides JS. Mixing in anaerobic digesters: University of Southampton; 2001.

54. Couper JR, Penney WR, Fair JR, Walas SM. Chemical Process

Equipment :Selection and Design. Oxford: Elsevier; 2005.

55. Salter A, Banks C. Anaerobic Digestion: Overall Energy Balances - Parasitic Inputs \& Beneficial Outputs. Sustainable Organic Resources Partnership - Advances in Biological Processes for Organics and Energy recycling; Birmingham2008.

56. US Enviromental Protection Agency. Process design manual for sludge treatment and disposal. 1979 EPA 625/1-79-011.

57. Energy Systems Research Unit. Case Study; investigated routes of disposal: University of Strathclyde 1998 [cited 2012 10/12]. Available from:

http://www.esru.strath.ac.uk/EandE/Web_sites/97-

8/energy_from_waste/page6.htm.

58. Banks C. Digester mass and energy balances. MSc Lecture part of CENV6141 Bioenergy2012.

59. Wu BX. Integration of mixing, heat transfer, and biochemical reaction kinetics in anaerobic methane fermentation. Biotechnology and Bioengineering. 2012 Nov; 109(1 1):2864-74. PubMed PMID: WOS:000309185600018. English. 60. Gilbert WG. Anaerobic digester mixing systems. Journal Water Pollution Control Federation. 1987 Mar;59(3):162-70. PubMed PMID:

WOS:A1987G613700008. English.

61. Meroney RN, Colorado PE. CFD simulation of mechanical draft tube mixing in anaerobic digester tanks. Water Res. 2009 Mar;43(4):1040-50. PubMed PMID:

WOS:000264328600019. English. 
62. Uzir MH, Mat Don M. Biochemical engineering - A concise introduction.

Penang: Universiti Sains Malaysia; 2007. Available from:

http://chemical.eng.usm.my/notes/HEKARL/notes/ekc471_notes.pdf.

63. Perry $\mathrm{RH}$, Chilton $\mathrm{CH}$. Chemical Engineers' Handbook. Fifth ed. Tokyo: McGraw Hill; 1973.

64. Mata-Alvarez J, editor. Biomethanization of the organic fraction of municipal solid wastes. London: IWA Publishing; 2003.

65. Borowitzka MA. Culturing of Microalgae in Outdoor Ponds. In: Andersen RA, editor. Algal Culturing Techniques. London: Elsevier; 2005.

66. Chiaramonti D, Prussi M, Casini D, Tredici MR, Rodolfi L, Bassi N, et al.

Review of energy balance in raceway ponds for microalgae cultivation: Re-thinking a traditional system is possible. Appl Energy. 2013 2//;102(0):101-11.

67. Lundquist TJ, Woertz IC, Quinn NWT, Benemann JR. A Realistic Technology and Engineering Assessment of Algae Biofuel Production. Berkeley, California:

Energy Biosciences Inst, 2010.

68. Jimenez C, Cossio BR, Niell FX. Relationship between physicochemical variables and productivity in open ponds for the production of Spirulina: a predictive model of algal yield. Aquaculture. 2003 May;221(1-4):331-45. PubMed PMID: ISI:000182383300026. English.

69. Johnson DA, Weissman JC, Goebel RP. An outdoor test facility for large scale production of microalgae. Golden, Colorado: SERI, 1988 SERI/TP-231-3325.

70. Purchas DB. Solid-liquid Separation Technology London: Uplands Press; 1981.

71. Axelsson H. Recent trends in disc bowl centrifuge development. Filtr Sep.

2000 May;37(4):20-3. PubMed PMID: WOS:000087286700002. English.

72. Ben-Amotz A. Marine algal systems. Towards Establishing Value Chains for Bioenergy; April; Swakopmund, Namibia: The African, Caribbean and Pacific Group of States (ACP) Science and Technology Programme; 2013.

73. Benemann J, Koopman B, Weissman J, Eisenberg D, Goebel R. Development of microalgae harvesting and high-rate pond technologies in California. In: Shelef G, Soeder CJ, editors. Algae Biomass. Amsterdam: Elsevier; 1980.

74. Zamalloa C, Vulsteke E, Albrecht J, Verstraete W. The techno-economic potential of renewable energy through the anaerobic digestion of microalgae. Bioresource Technology. 2011 Jan;102(2):1149-58. PubMed PMID: ISI:000286782700100. English.

75. Gavala HN, Yenal U, Skiadas IV, Westermann P, Ahring BK. Mesophilic and thermophilic anaerobic digestion of primary and secondary sludge. Effect of pretreatment at elevated temperature. Water Res. 2003 11//;37(19):4561-72.

76. Espinosa-Solares T, Bombardiere J, Chatfield M, Domaschko M, Easter M, Stafford DA, et al. Macroscopic mass and energy balance of a pilot plant anaerobic bioreactor operated under thermophilic conditions. Applied biochemistry and biotechnology. 2006 2006;129-132:959-68. PubMed PMID: MEDLINE:16915704. English.

77. Spirax Sarco. Energy Consumption of Tanks and Vats 2012 [cited 2012 10/12]. Available from: http://www.spiraxsarco.com/resources/steam-engineeringtutorials/steam-engineering-principles-and-heat-transfer/energy-consumption-oftanks-and-vats.asp.

78. Wang LK, Pereira NC, Hung TT. Biological Treatment Processes. Shammas NK, editor. New York: Humana; 2009.

79. Basrawi F, Yamada T, Nakanishi K. Effect of Ambient Temperature on the Energy Balance of Anaerobic Digestion Plants. Journal of Environment and Engineering. 2010;5(3):526-38.

80. Verma NM, Mehrotra S, Shukla A, Mishra BN. Prospective of biodiesel production utilizing microalgae as the cell factories: A comprehensive discussion. 
Afr J Biotechnol. 2010 Mar;9(10):1402-11. PubMed PMID: ISI:000275890700002. English.

81. Moheimani N, Borowitzka M. The long-term culture of the coccolithophore \& leurochrysis carterae (Haptophyta) in outdoor raceway ponds. J Appl Phycol.

2006;1 8(6):703-12.

82. Olguín EJ. Phycoremediation: key issues for cost-effective nutrient removal processes. Biotechnol Adv. 2003;22(1-2):81-91.

83. Mata TM, Martins AA, Caetano NS. Microalgae for biodiesel production and other applications: A review. Renew Sust Energ Rev. 2010 Jan;14(1):217-32. PubMed PMID: ISI:000271279100012. English.

84. Shen Y, Yuan W, Pei ZJ, Wu Q, Mao E. Microalgae mass production methods. Trans ASABE. 2009 Jul-Aug;52(4):1275-87. PubMed PMID: ISI:000269783100024. English.

85. Senior J, Saenger N, Muller G. New hydropower converters for very low-head differences. Journal of Hydraulic Research. 2010;48(6):703-14. PubMed PMID:

ISI:000285348800001. English.

86. Green FB, Lundquist TJ, Oswald WJ. Energetics of advanced integrated wastewater pond systems. Water Sci Technol. 1995;31(12):9-20. PubMed PMID:

ISI:A1 995TG76900003. English.

87. Benemann J, Oswald WJ. Systems and economic analysis of microalgae ponds for conversion of $\mathrm{CO} 2$ to Biomass. Pittsburgh: Pittsburgh Energy Technology Centre, 1996 Contract No.: DE-FG22-93PC93204 () DOE/PC/93204--T5).

88. Ketheesan B, Nirmalakhandan N. Development of a new airlift-driven raceway reactor for algal cultivation. Appl Energy. 2011 ; In Press, Corrected Proof.

89. Sorguven E, Ozilgen M. Thermodynamic assessment of algal biodiesel utilization. Renew Energy. 2010 Sep;35(9):1956-66. PubMed PMID:

WOS:000277894000011. English. 